\title{
ІНФОРМАЦІЙНЕ ЗАБЕЗПЕЧЕННЯ КОРЕКЦІЇ ТА ПРОФІЛАКТИКИ ЗОРОВИХ РОЗЛАДІВ В ДІТЕЙ ТА ПІДЛІТКІВ
}

\author{
А. В. Яворський, М. Л. Кочина ${ }^{1}$ \\ Харківський національний медичний університет \\ ${ }^{1}$ Харківська медична академія післядипломної освіти
}

\section{INFORMATIVE PROVIDING FOR CORRECTION AND PROPHYLAXIS OF VISUAL DISORDERS DURING CHILDREN AND TEENAGERS}

\author{
Kharkiv National Medical University, ${ }^{1}$ Kharkiv Medical Academy of Postgraduate Education
}

Вступ. Основним показником, за яким прийнято визначати стан зорових функцій при диспансеризації дітей та підлітків в Україні перед вступом до школи і при щорічних медичних оглядах учнів, $є$ гострота зору (ГЗ). Багато фахівців відмічають, що висока ГЗ зберігається при повній відсутності або низьких значеннях функціональних резервів зорової системи (3С). Високі функціональні резерви забезпечують зорову працездатність тривалий час, низькі або повна їх відсутність призводять до швидкого розвитку зорової втоми або появи спазму акомодації. У зв'язку з цим, окрім ГЗ, необхідно проводити дослідження інших зорових функцій.

Результати та їх обговорення. Результати нашого дослідження показали значну інформативність позитивних резервів акомодації $(\mathrm{Pa})$ обох очей для дальньої відстані, найближчих точок ясного зору (Нк) обох очей і найближчої точки конвергенції (Нкк).

На основі результатів, отриманих за допомогою нечіткої кластеризації та регресійних моделей віднесення досліджуваних до відповідних кластерів, 3 урахуванням виявлених принципів і механізмів формування ЗС, розроблено метод визначення структурно-функціональної організації 3С дітей та підлітків на етапі одержання та первинної обробки візуальної інформації для формування індивідуальних профілактичних заходів.

На першому етапі розробленого методу визначають ГЗ досліджуваних, після чого здійснюється їх поділ на дві основні групи. Якщо ГЗ менше норми, тобто нижче 1 на кожне око, то досліджуваного направляють до спеціалізованого лікувального закладу (якщо огляд проводився, наприклад, в школі або ВНЗ) для виявлення причини зниження ГЗ, призначення відповідної корекції наявної патології, що $є$ профілактикою погіршення зорових функцій. Якщо ГЗ в нормі, на другому етапі визначають виділені функціональні показники 3С (Pa OD и OS, Нк OD и OS, Нкк). На третьому етапі за допомогою регресійної моделі для відповідної вікової групи, 3 використанням визначених показників 3С, досліджуваного відносять до одного 3 кластерів. На четвертому етапі, залежно від визначеного кластера, для кожного досліджуваного формується індивідуальна програма профілактики зорових розладів.

Для скорочення часу проведення досліджень, особливо в умовах шкіл або ВНЗ, нами було розроблено інформаційну систему визначення структурнофункціональної організації 3С «Профілактика зорових розладів», яка може також використовуватися в дитячих офтальмологічних кабінетах поліклінік та в офтальмологічних стаціонарах.

Висновок. Важливим завданням сучасної офтальмології $\epsilon$ виявлення дітей та підлітків із ризиком розвитку зорових розладів, визначення типу ризику та формування на цій основі комплексу профілактичних заходів, що може бути вирішено за допомогою запропонованої інформаційної системи.

Для створення системи використано запропонований метод визначення структурно-функціональної організації 3С, що дозволяє сформувати групи ризику дітей та підлітків щодо розвитку зорових розладів та розробити індивідуальні комплекси заходів для їх профілактики. До основних модулів системи відносяться: модуль вхідних даних, база даних, модулі аналізу даних та інтерпретації результатів, додаток користувача.

(C) А. В. Яворський, М. Л. Кочина 